\title{
Stargardt Disease
}

National Cancer Institute

\section{Source}

National Cancer Institute. Stargardt Disease. NCI Thesaurus. Code C85078.

An autosomal recessive and rarely autosomal dominant inherited disorder caused by mutations in the ABCA4 or ELOVL4 genes respectively. It is characterized by macular degeneration that begins in late childhood resulting in progressive loss of vision. 